\title{
Localisation Buccale Secondaire D'un Carcinome Renal
}

\author{
Ikrame Boumendil ${ }^{1 *}$, Taha Ismail Sefrioui ${ }^{1}$, Hajar Ait Taleb ${ }^{1}$, Sophia Nitassi ${ }^{2}$, Abdelilah Oujilal ${ }^{2}$, Leila Essakalli ${ }^{2}$ \\ ${ }^{1}$ Resident in otolaryngology and cervical-facial surgery, Hospital of specialties, Mohammed V University, Rabat, Morocco. \\ ${ }^{2}$ Professor in the service of otorhinolaryngology and cervical-facial surgery, Hospital of specialties, Mohammed V University, Rabat, Morocco.
}

Corresponding Author: Ikrame Boumendil, Resident in otolaryngology and cervical-facial surgery, Hospital of specialties, Mohammed V University, Rabat, Morocco.

Received date: May 19, 2021; Accepted date: August 10, 2021; Published date: January 05, 2022

Citation: Ikrame Boumendil, Taha Ismail Sefrioui, Hajar Ait Taleb, Sophia Nitassi, Abdelilah Oujilal, Leila Essakalli (2022) Localisation Buccale Secondaire D'un Carcinome Renal. J, Surgical Case Reports and Images 5(1); DOI: 10.31579/2690-1897/081

Copyright: (C) 2022, Ikrame Boumendil, This is an open access article distributed under the Creative Commons Attribution License, which permits unrestricted use, distribution, and reproduction in any medium, provided the original work is properly cited.

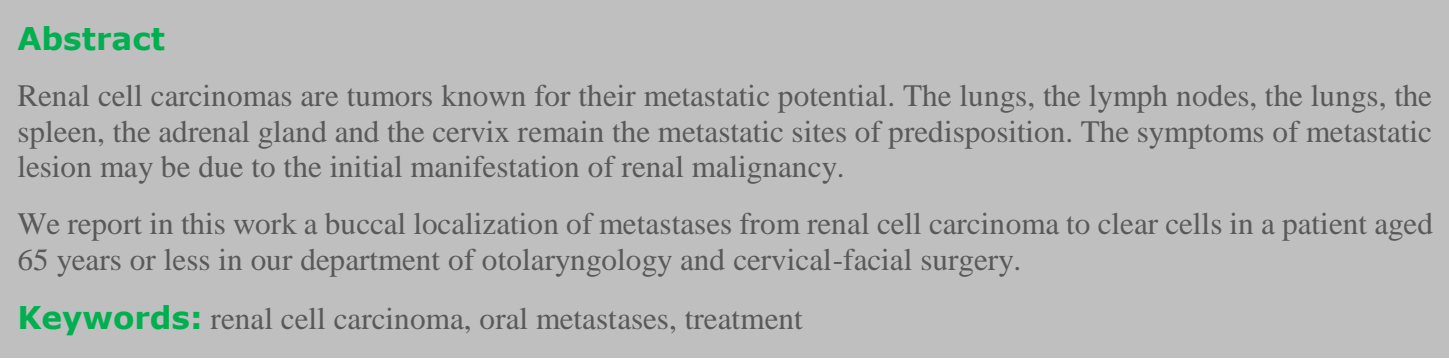

\section{Introduction}

Metastases representing 1\% of malignant tumors of the oral sphere [1]. In $25 \%$ of cases, the Oral sphere is the primary localization of a known cancer and in $23 \%$ there is the first signaling sign of a malignant tumor in another organ [2]. These metastases are at the level of the mandible in $82 \%$ and the attached gensive is implicated in $54 \%$. The most common symptoms are: tumors, doubles or paresthesia. Renal origin of these oral metastases represents $8.5 \%$ in women and $11 \%$ in men, after genital and pulmonary tumors [2].

Present in which a gingival metastasis occurs in a patient over 65 years of age with flexible therapy for clear cell carcinoma of the kidney.

\section{Clinical observation}

A 65-year-old patient was diagnosed with arterial hypertension due to a balanced palliative nephrectomy or one or two patients receiving adjunctive therapy (Sunitinib). The patient is addressed in our formation before the apparatus of a mass at the level of the forearm, marked by the contact of the augmentation feeding from the tail to the 3 semenes.
The endobuccal axis reveals a process sessile at the level of the lateralized lateral fold in terms of teeth 16 and 17, sensitive, of farm consistency, measuring by contact measuring $20 \mathrm{~mm}$ (Fig1). The rest of the ENT's condition is notable especially for palpable adenopathy.

A massive facial tomodensitometry performed objectively on the lateral lateral tissue process measuring $14 * 8 * 16 \mathrm{~mm}$ with erosion of the mandibular cortex with respect to the tooth 16 protruding from the maxillary sinus periodontal with respect to 16 on probable buccosinusoidal communication.

The patient undergoes a large biopsy of the tumor. The anatomopathological examination reveals a small buccal ulcer ulcerated on the surface and infiltrated by a carcinomatous process of cordial, acinar and trabecular architecture, composed of cells of large, polyhedral, strongly oval, convex oval cytoplasm abundant and clear, the stroma is green, of vascular nature. In favor of a gingival localization of carcinoma with clear renal cone cell.

The anti-angiogenic but palliative treatment Sunitinib (SutentW) $50 \mathrm{mg} /$ $\mathrm{j}, 4$ sessions / 6 was continued. The current recalculation is from 8 months. 


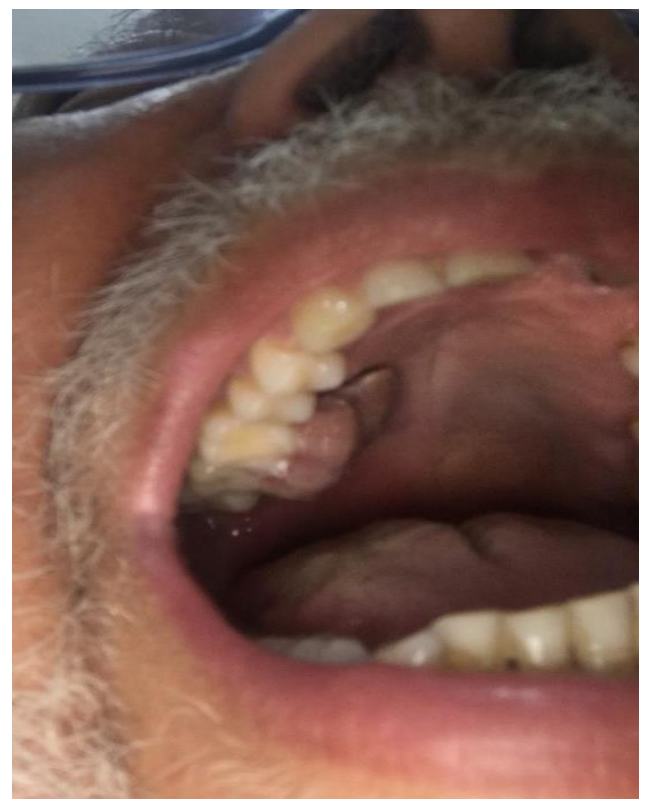

Figure1: Image of the location of the metastatic lesion at the level of the palatine gens in terms of teeth 16 and 17 forming a benign tumor.

\section{Discussion}

Three percent $(3 \%)$ of adult cancers affect the kidney, and $80 \%$ of these tumors are present in clear cell carcinomas. The evolution of these cancers is noticeable, with a tendency to metastasize to all regions of the body that become more revelatory to renal disease. The most frequent metastatic sites are the lung (50 à 60\% of cases), the lymphatic ganglia (15 à 30\%), the os (30 à $40 \%)$, the foie gras (28\%), the adrenal glands (10 à 15$) \%$ ) et le cerveau (10 à 13\%). The head region and corresponding to $6 \%$ of distance metastases [3]. Three otolaryngological (LRL) sites are most commonly affected by renal origin metastases: the para-nasal and maxillary sinuses, the thyroid, and the parotid gland [4].

In general, metastases are situated in the head region and where they are hematogenous from pulmonary metastases. However, cases of cervicocephalic metastases are detected in the absence of pulmonary localizations; where these metastases are transiting through the vertebral vein plexus or thoracic canal [5]. The patient's case does not have the following pulmonary lesion.

Oral metastases can be the first clinical manifestation of a malignant tumor, and this is due to the object of various publications [6]. It is not uncommon for these metastases to be present clinically, or histologically, as benign tumors of the genitals or as local inflammatory lesions of the epulis, pyogenic granuloma, or 7-cell granuloma. This is the case of our patient, regardless of the aspect of the lesion as well as the suspicion of buccal-dental communication.

The treatment of renal cell metastases should be individualized according to the location of the tumor and the general condition of the patient. Excision of soluble metastatic lesions after nephrectomy resulted in a survival of $41 \%$ in both cohorts and $13 \%$ in cesarean section, independent of the time between nephrectomy and diagnostic of the secondary lesion [8].

Radiation resistance of metastases, some of which result in postoperative radiotherapy of cervico-facial localizations to improve local control [9]. Chemotherapy is still effective [3]. Immunotherapy is the only treatment with actual curative treatment, the reference treatment being antiangiogenic which has superior efficacy and tolerance to other cytotoxic therapies [10].
The metastatic cancer present by definition is a pejorative pronoun with a survival rate of 5 to 7 at $13 \%$. Multiple predictive factors influencing patient survival [3].

\section{Conclusion}

Malgré of stimulant results, metastatic renal cancer remains particularly pejorative. Surgical approach remains the best therapeutic option when metastasis is unique and researchable. Therapeutic associations are inadmissible for improving the orthostatic of patients.

Oral localization of renal origin metastases is rare. However, any annuities may occur after the renal primitive has been removed, justifying the search for the antecedent wire in the patient's anamnesis due to a malignant lesion of the buccal cavity.

\section{Conflicts of interest}

The authors do not declare any conflict of interest.

\section{Contributions from authors}

All authors contributed to this work. The final version of the manuscript has already been approved.

\section{Reference:}

1. Van der Waal R I, Buter J, van der Waal I. (2003) Oral metastases: report of 24 cases. Br J Oral Maxil- lofac Surg 41: 3-6.

2. Hirshberg A, Shnaiderman-Shapiro A, Kaplan I, Berger R. (2008) Metastatic tumours to the oral cav-ity - pathogenesis and analysis of 673 cases. Oral Oncol 44: 743-752.

3. Vidart A, Fehri K, Pfister C. (2006) Unusual metastasis of renal carcinoma. Annales d'urologie. 40. 211-219.

4. Ishak AI, Pauzi SH, Massir N, See GB. (2010) Multiple metastatic deposits in the head and neck region from a renal cell carcinoma. Malaysian J Med Sci.17(4):71-4.

5. Azam F, Abubakerr M, Gollins S. (2008) Tongue metastasis as an initial presentation of renal cell carci- noma: a case report and literature review. J Med Case Reports. 2: 249. 
6. Makos C P, Psomaderis K. (2009) A literature review in renal carcinoma metastasis to the oral mucosa and a new report of an epulis-like metastasis. J Oral Maxillofac Surg. 67: 653-660.

7. Heinroth S, Bilkenroth U, Eckert A W, Maurer P. (2006) Bone metastases in the maxilla as first mani- festation of renal cell cancer. A case report. Mund Kiefer Gesichtschir. 10: 42-45.

8. Patard HJ, Baumert J, Correas M, et al. (2010) Recommandations en uro-oncologie. Prog Urol, 20, 319-39.
9. Hamdoon Z, Jerjes W, Upile T, Akram S, Hopper C. (2010) Metastatic renal cell carcinoma to the orofacial region: a novel method to alleviate symptoms and control disease progression. Photodiagnosis Photodyn Ther, 7:246-50.

10. Méjean A, Lebret T. (2008) Prise en charge du cancer rénal me'tastatique. Progr Urol, (Suppl. 7):S298-308
This work is licensed under Creative Commons Attribution 4.0 License

To Submit Your Article Click Here: Submit Manuscript

DOI: $10.31579 / 2690-1897 / 081$
Ready to submit your research? Choose Auctores and benefit from:

* fast, convenient online submission

* rigorous peer review by experienced research in your field

* rapid publication on acceptance

* authors retain copyrights

* unique DOI for all articles

* immediate, unrestricted online access

At Auctores, research is always in progress.

Learn more auctoresonline.org/journals/journal-of-surgical-case-reportsand-images 